\author{
Review Article \\ www.ijrap.net (ISSN:2229-3566)
}

\title{
CRITICAL INSIGHT IN CONCEPT OF TRIGUNA: A REVIEW
}

M R Sandhya ${ }^{1 *}, \mathrm{M} \mathrm{V}$ Vinodkumar $^{2}$

${ }^{1}$ PG Scholar, Department of Samhita, Sanskrit and Siddhanta, V P S V Ayurveda College, Kottakkal, Kerala, India

${ }^{2}$ Professor, Department of Samhita, Sanskrit and Siddhanta, V P S V Ayurveda College, Kottakkal, Kerala, India

Received on: 19/04/21 Accepted on: 18/06/21

\author{
*Corresponding author \\ E-mail: sandhya.manampilly@gmail.com
}

DOI: $10.7897 / 2277-4343.120391$

\begin{abstract}
Theory of Triguna, originally explained in Sankhya Darshana and accepted in Ayurveda, says that the whole universe is composed of three major attributes namely Satwa, Raja and Tama. The living being, with its physique and psyche, represents the universe, hence, is made up of these three major attributes. The relationship of triguna with Panchamahabhuta, Tridosha and Shadchakra are already studied. Transactional analysis and triguna are interrelated. Basic emotions of human beings are love, hatred and fear. They generate need, action and confusion. These three qualities are interdependent, complementary and antagonistic at the same time. Wellness of human beings incorporates eight mutually interdependent dimensions. All these dimensions cannot be satisfied by a personality with a single guna, but a combination of Satwa, Raja and Tamo guna play here. Similarly multiple intelligences in a person depend on the predominant guna present in them. By understanding and promoting the multiple intelligences in a person helps to shine them in their own world. This paper is a prime attempt to put light on the concept of triguna.
\end{abstract}

Keywords: Triguna, Siddhanta, Shadchakra, transactional analysis, wellness, multiple intelligences

\section{INTRODUCTION}

Ayurveda adopted many theories from different philosophical traits in India (Darshana) with suitable modifications necessitated for application for curing diseases. Sankhya Darshana, one of the major Six Darshanas, explains the material content of the world to be consisting of Three Attributes (Triguna) such as Satwa, Rajas and Tamas. Even though triguna structure explains anything in the universe, it is specifically applied in the context of psychology, for the reason that, the attributes of triguna are more traceable for mind rather than physique. In Ayurveda, triguna explains chiefly the formation of psychological features of a person, characterization of personality traits, predisposing factors for mental diseases (especially Rajas and Tamas) and method of attainment of salvation (increase in Satwa). Many attempts have been made to compare the triguna nature of human mind with suitable counterparts in modern psychology. Psychology, being an evolving and indelible aspect of human nature, there are still some areas through which triguna can be explored for better understanding in the contemporary scenario.

As per Sankhya darsana, the whole universe is composed of three major attributes namely satwa, raja and tama. The living being represents the microcosm of the universe, body and mind of living being is made up of these three major attributes. Early explanation of this theory can be seen in Bhagavat Geeta and Svetasvatara Upanishad.

\section{Positioning of Triguna siddhanta}

Triguna is considered as a theory, when placed in a hierarchy, remaining in an intermediate level. As per Sankhya darsana, Triguna are basic attributes of Primordial nature (Mulaprakriti) from where all the other evolutes are evolved. The evolution ends up in Panchabhoota, from where the material world formed in gross form. Human beings are the epitome of Universe (Loka- purusha samya sidhanta), changes in human body and surroundings obey the rule of Similars and Dissimilars (samanyavisesha sidhanta) and things are fundamentally connected through Cause $=$ effect relationship (karya-karana sidhanta) In the hierarchy Triguna Sidhanta remains just above the three major principles as stated above, because the former obeys the latter rules. Panchabhoota, Tridosha etc. appear above in the hierarchy because they are derivatives of Triguna sidhanta. Sushruta makes categorical correlation of Triguna with Panchabhoota. Akasa is predominant of satwaguna, vayu predominant of rajoguna and prithwi with tamoguna. Agni mahabhoota is the combination of satwa and rajas and jala mahabhoota is the combination of satwa and tamo guna ${ }^{1}$. Acharya Bhavamisra explored Tridosha-Triguna relationship by stating that vata is rajoguna predominant pitta is predominantly satwaguna and kapha is with tamoguna ${ }^{2}$.

\section{Classification of food based on triguna}

Classification of food according to triguna is mentioned in Bhagavat Geeta. Foods that promote life, firmness of mind, strength, health, pleasure, and delight, and which are delicious, juicy, and nourishing are dear to one possessed of satwa ${ }^{3}$. Example ghee, milk etc. Foods which are bitter, sour, salty and pungent in taste, very hot, dry, and burning, and which produce unhappiness, sorrowfulness and disease are dear to one endowed with rajas ${ }^{4}$. Example pickle, garlic, coffee, tea etc. Food that is not properly cooked, tasteless, decayed and foul and that which is unfit for sacrifice, is dear to one endowed with tamas 5 . Examples are frozen food items.

\section{Correlation with contemporary science}

Sushruta Acharya has said that one should learn many sciences. Then only the treatment becomes proper ${ }^{6}$. In research also there is a golden triangle partnership with CCRAS, CSIR and ICMR. Their motto is science should be contemporary. Comparison of 
modern knowledge and Ayurvedic psychology is explained grossly in Table 1.

\section{Physiological understanding of triguna}

Even though triguna pertains to a psychological domain of human affairs, the physiological realm also is equally important in the context of triguna. Satwa is explained as an abode of knowledge (Jnana). In physiology, receiving of impulse and proper understanding of situation is done by the predominance of Satwa. After receiving of an impulse, the resultant action (active phase) is brought about by Rajas, because Rajas is the active part (Pravartaka) of the three. After initiating activity, definitely there will be a point where the activity is to be controlled and inhibited. Such an inhibition is brought about by Tamas, because Tamas by nature is inhibition (Niyamaka).

\section{Psychological understanding of triguna}

We are acquiring proper orientation through Satwa guna and psychomotor activity is initiated with the help of Rajo guna and inhibition of such activity by Tamo guna. Simply, all the three qualities are equally important. All three attributes will be present in every person. According to the predominance we are calling as Satwika, Rajasika and Tamasika prakriti.

In psychology if personality is considered, Rajasika predominant person will be coming under 'type a' personality, who are aggressive in nature. They are competitive, move fast and do things quickly as if they don't have so much time to spare. They are ambitious. But they are not good at maintaining relationships and are stressed. A Tamasika predominant person will be having passive behavior. So we can include them under 'type b' personality ${ }^{7}$. They will maintain a calm attitude always. They are easy going and tolerant. Satwa is also passive, but with proper orientation. Tamas will be passive and without knowledge or orientation.

\section{Psychoanalysis and Transactional Analysis (TA) in triguna}

Sigmund Freud's personality theory saw the psyche structured into three parts; id, ego and superego, all developing at different stages in our lives. ${ }^{8}$ Id represents pleasure principle (uncoordinated instinctual desire), ego symbolizes reality principle and superego represents morality principle. For better understanding we can compare Id with Tamas, ego with Rajas and superego Satwa. Transaction analysis is a psychoanalytic theory used to decide the ego state of the communicator; parent child or adult. Child ego state is comparable with Tamas, because child's activities are more driven by ignorance. Even though they are active, in infancy the activities are more or less meaningless when compared to adult state. Adult ego state is Satwa predominant because it prepares a person to analyze things unbiased avoiding preconceptions. Parent ego state is partially Satwa predominant and equally Raja predominant. A nurturing parent will be Satwika whereas criticizing parent will be Raja predominant.

\section{Shadchakra and triguna}

Concept of Shadchakra is explained in Hatha yoga. They are Mooladhara, Swadhishtana, Manipooraka, Anahata, Vishuddha and Ajna. $7^{\text {th }}$ one is Sahasrara. These chakras run along our spine. They start at the base or root of our spine and extend to the crown of our head. These represent the energy system in our body. To function properly, our chakras need to be stay open or balanced. The base chakra, Mooladhara represents our basic needs that are security and stability. Swadhishtana is for sexual and creative energy. Manipooraka is responsible for self-esteem and confidence. Anahata for love Vishuddha for verbal communication and Ajna are responsible for intuition. $7^{\text {th }}$ one Sahasrara is responsible for the spiritual connection to yourself, others and universe ${ }^{9}$. The journey from Mooladhara to Sahasrara represents same from Tamo guna to Satwa guna.

\section{Classification of Manasa Prakruti (Psychic constitution of body)}

Since triguna explains the basic stimulus-response mechanism of human mind, behavior and personality traits are well integrated with concept of triguna. Personality traits (Manasa Prakruti) are of many types based on predominance Satwa Raja and Tamo guna. They subdivided into 16; 7 Satwika Prakruti, 6 Rajasa Prakruti and 3 Tamasa Prakruti ${ }^{10}$. Each has a different characteristic feature. Even though the features of Manasa Prakriti are explained explicitly, key features of each prakriti can be enlisted as Table 2 .

\section{Wellness and triguna}

Wellness is a holistic integration of mental, physical and spiritual well-being and is "a lifestyle and a personalized approach to living life in a way that... allows you to become the best kind of person that your potentials, circumstances, and fate will allow"11

Wellness incorporates 8 mutually interdependent dimensions

1. Physical

2. Emotional

3. Social

4. Financial

5. Spiritual

6. Professional

7. Intellectual

8. Environmental

In Ayurveda a total of 16 types of Manasa Prakritis are explained. These are manifested with the influence of Satwa Raja and Tamo guna. The characteristics of these 16 personalities can be compared with the dimensions of wellness. All these dimensions cannot be satisfied by a personality with single attribute. Only combination will work.

\section{Multiple intelligence and triguna}

Theory of multiple intelligences is introduced by Gardner. There are eight types of multiple intelligences. This ranges from use of words, pictures, numbers and music to social interaction, physical movements and being attached with nature ${ }^{12}$. Every individual has a special inborn skill in them. Some may realize it earlier and live happily by achieving their passion. But some others spoil their life without realizing the multiple intelligences in them. In Ayurveda, we can compare it with the 16 types of personality (Table 3).

Multiple intelligences in a person depend on the predominant attribute present in them. By understanding and promoting the multiple intelligences in a person helps to shine them in their own world. It will give them a good career.

\section{Functioning of triguna}

The functioning of triguna is for a single purpose, like that of a lamp. Now Satwa and Tamas are attributes which are inactive by themselves, and are therefore unable to produce their own effects, 
derive their driving force from Rajas which rouses them from their inertia and excites them to accomplish their own respective effects. Through this it is indicated that the operation of Rajas is necessary for all activity. The Rajo guna because of mobility keeps the three attributes in a continuous state of activity but it is operative only in some cases because of its mobility getting restrained by sluggish and obscuring qualities of Tamas.

Their functioning is for a common purpose like that of a lamp. It is a matter of common observation that the wick and oil though opposed to the action of fire, when brought together, they cooperate to perform the task of giving light. Similarly, the Tridosha - vata, pitta and kapha though possessed of mutually opposite properties, cooperate with each other for the sole purpose of sustaining the body.

\section{Purpose of knowing triguna}

These three attributes are interdependent and antagonistic and at the same time complementary to each other. Although all three kinds of attributes are seen everywhere in this creation, the human mind must be cultivated and trained in order to cultivate Satwika guna as much as possible. In order to contend with global challenges, Ayurveda experts need profound knowledge of various conditions causing diseases, their symptoms, investigations to be performed to diagnose diseases and their treatment. With the change in lifestyle and the hectic daily schedule, new diseases with fatal consequences are fast emerging. It is essential for Ayurvedic experts to be well aware of the knowledge existing in the medical world and have a proper understanding of pathology of the illness in the enlightenment of our Ayurvedic principles. According to Ayurveda, disease is an auxiliary multifaceted psychosomatic incident. Ayurvedic literature affirms the association between the body and intellect in its approach to illness as well as wellbeing at various places. However the vitiated Doshas, Dhatus and Malas linger the physiological foundation of disease. Vata, pitta and kapha are the three physiological or 'Sharirik Doshas'. Ayurveda conceptualizes that apart from these three, there are two others predominantly psychological dosha too, Mansik Doshas- Rajas and Tamas. It is a well-established fact that body and mind treat each other in various consequences.

Table 1: Correlation with contemporary science

\begin{tabular}{|c|c|}
\hline Modern Psychology & Ayurveda \\
\hline $\begin{array}{l}\text { Psyche - a single unit- no difference between soul and } \\
\text { consciousness }\end{array}$ & $\begin{array}{l}\text { Manas separate form atma. } \\
\text { Atma is the authority and Manas the Programme co-coordinator }\end{array}$ \\
\hline Two entities - psyche and body & Four entities-body, mind, faculties and soul \\
\hline $\begin{array}{l}\text { Psyche is defined as part of a person consisting of thoughts } \\
\text { (cognition), feelings (affect) and the function of willing (volition) }\end{array}$ & $\begin{array}{l}\text { Mind is super faculty that is the causative faculty for knowledge of } \\
\text { happiness, unhappiness etc. }\end{array}$ \\
\hline $\begin{array}{c}\text { In modern science, mind is explored in terms of body- matter } \\
\text { relationships }\end{array}$ & Ayurveda considers mind as body distinct from matter \\
\hline Mind is labeled as a particular level of biological function & Mind as master of body and its functions \\
\hline Mind-body mutually not agreed & Mind-body mutually strongly approved and illustrated \\
\hline Mind is considered as a biophysical entity & $\begin{array}{l}\text { Does not considered as a biophysical entity because it says that mind } \\
\text { travels from one life to another to attain continuity of deals }\end{array}$ \\
\hline
\end{tabular}

Table 2: Key features of each prakriti

\begin{tabular}{|c|c|}
\hline Personality traits & Key features \\
\hline Brahma & Self-control, equanimity \\
\hline Aarsha & Ritualistic \\
\hline Aindra & Trustworthiness, farsightedness \\
\hline Yamya & Perfect time management, obeying rules \\
\hline Varuna & Perfectionism, expression of anger and happiness in proper time and place \\
\hline Kaubera & Fuxurious and virtuousness \\
\hline Gandharva & Aggressive and competitive \\
\hline Asura & Cool. Agitated only when provoked \\
\hline Sarpa & Always wandering \\
\hline Sakunam & Exploitation of other's weakness \\
\hline Rakshasa & Adventurous and sexual perversion \\
\hline Pisaca & Depressive and isolative \\
\hline Preta & No acceptance of others \\
\hline Paasava & Flight of ideas or fluctuating ideas \\
\hline Matsya & Absence of cognitive skills \\
\hline Vanaspatya & \\
\hline
\end{tabular}

Table 3: Multiple intelligence and personality

\begin{tabular}{|l|c|}
\hline \multicolumn{1}{|c|}{ Multiple intelligence } & Personality \\
\hline 1. Visual-Spatial Intelligence & Aindra kaya (Farsightedness, imagination, film field) \\
\hline 2. Linguistic-Verbal Intelligence & Aindra kaya (Giving trustworthy words) \\
\hline 3. Logical-Mathematical Intelligence & Yamya kaya (Timely instigation of dealings, Observance of the humility of actions) \\
\hline 4. Bodily-Kinesthetic Intelligence & Gandharva kaya (Fond of art forms, esthetics) \\
\hline 5. Musical Intelligence & Gandharva kaya (Fond of art forms) \\
\hline 6. Interpersonal Intelligence & Mahendra kaya (Leadership quality) \\
\hline 7. Intrapersonal Intelligence & Varuna kaya (Perfectionist) \\
\hline 8. Naturalistic Intelligence & Matsya kaya, Sakuna kaya (Finding patterns and relationships to nature) \\
\hline
\end{tabular}




\section{CONCLUSION}

All three gunas are equally important for a human being. For the very basic things like sleeping (Nidra hetu) Tama is important, for awakening, Satwa is needed and in the case of dreams Rajas plays an important role. They are mutually dominating, supporting, productive and co-operating.

Understanding of triguna is essential for the maintenance of health as well as prescription of treatment.

\section{REFERENCES}

1. JT editor. Sushruta Samhita of Sushruta, (Nibandha Sangraha, Dalhana commentary Sanskrit) Varanasi: Chaukhambha Sanskrit Sansthan; 2017. p. 343; 1/ 20.

2. Bhavamishra. Garbhaprakaranam in Bhavaprakash, (Bulusu Sitaram. comm. English) Varanasi: Chaukhambha Orientalia; 2015. p. 102,120,126.

3. Swami Chinmayananda. Shreemad Bhagavat Geeta, (Gopalan, Krishnankutty, translation) Ernakulum: Chinmaya publications; 2010. p. 762;17/8

4. Swami Chinmayananda. Shreemad Bhagavat Geeta, (Gopalan, Krishnankutty, translation) Ernakulum: Chinmaya publications; 2010. p. 763; 17/9

5. Swami Chinmayananda. Shreemad Bhagavat Geeta, (Gopalan, Krishnankutty, translation) Ernakulum: Chinmaya publications; 2010. p. 763; 17/10

6. JT editor. Sushruta Samhita of Sushruta, (Nibandha Sangraha, Dalhana commentary, Sanskrit) Varanasi: Chaukhambha Sanskrit Sansthan; 2017. p. 18; 4/ 77.
7. McLeod, S.A. Type A and Type B Personality Theory [Internet]. Simply Psychology; 2017. Available at: https://www.simplypsychology.org/personality-a.html

8. McLeod, S. A. Id, ego and superego [Internet]. Simply Psychology; 2019, September 25. Available at: www.simplypsychology.org/psyche.html

9. Pradnya Dr. Chakra-Kundalini: Introduction, Meaning, Types, Location, Ayurveda View. [Internet]. Easy Ayurveda; 2019 November 4. Available from: www.easyayurveda.com/2017/11/30/chakras-kundaliniayurveda/.

10. Yadavaji Trikamaji ed. Charaka Samhita (Ayurveda Dipika commentary Sanskrit) Varanasi; Chaukhambha Surbharati Prakashan; 2009. p. 323; 4/37-39.

11. Why 8 Aspects of Wellness? [Internet]. Samaritan Health Plans; 2016 June 29. Available from: www.samhealth plans.org/about-samaritan-health-plans/why-8-aspects-ofwellness

12. Multiple Intelligences Definition and Meaning. [Internet]. Top Hat; 2019 September 16. tophat.com/glossary/m/ multiple-intelligences

\section{Cite this article as:}

M R Sandhya and M V Vinodkumar. Critical insight in concept of Triguna: A Review. Int. J. Res. Ayurveda Pharm. 2021;12(3):143-146 $\quad$ http://dx.doi.org/10.7897/22774343.120391

\section{Source of support: Nil, Conflict of interest: None Declared}

Disclaimer: IJRAP is solely owned by Moksha Publishing House - A non-profit publishing house, dedicated to publishing quality research, while every effort has been taken to verify the accuracy of the content published in our Journal. IJRAP cannot accept any responsibility or liability for the site content and articles published. The views expressed in articles by our contributing authors are not necessarily those of IJRAP editor or editorial board members. 